\title{
HUBUNGAN ANTARA PENATAAN SITUASI BELAJAR SISWA DENGAN HASIL BELAJAR AKIDAH AKHLAK DI KELAS V MI NURUL HUDA KAPONGAN SITUBONDO
}

\author{
Zainal Arifin ${ }^{1}$ \\ STAI Nurul Huda Kapongan Situbondo \\ arifinstainh275@gmail.com
}

\begin{abstract}
The role of the teacher in classroom management is very important to create a quality learning atmosphere. In principle, the teacher holds two main tasks, namely teaching and classroom management. Teachers as professional educators have a very complex role, not limited to learning activities, teachers also serve as administrators, evaluators, counselors. Management is an art of getting everything done through other people. A good learning process will minimize the possibility of failures and mistakes in learning. It is important for teachers to have the ability to create good teaching and learning conditions and to achieve optimal levels of effectiveness in instructional activities for classroom management skills. The purpose of this research is to prove whether or not there is a relationship between structuring student learning situations and learning outcomes of Islamic education. To achieve the research objectives, a quantitative approach with correlation is used. To obtain accurate research information, the research instrument used was a checklist scale and a document on student learning outcomes. Then the data obtained were analyzed using statistical analysis and product moment formula. The results of this study explain $5 \%$ of 0.250 from a $1 \%$ confidence interval of 0.325 , with $N=60$, and the value of $r x y=1.26$. So the results of the research analysis explain that there is a relationship between structuring student learning situations and learning outcomes of Islamic education at MI Nurul Huda Kapongan Situbondo. As for students who use structuring learning situations that are good will get better results than students who do not use structuring learning situations that are not good, of course it will affect the results of these students' learning skills, so that they get unsatisfactory results.
\end{abstract}

Keywords: Islamic Religious Education, Learning Situation, Learning Outcomes

\begin{abstract}
Abstrak
Peran guru dalam pengelolaan kelas sangat penting untuk menciptakan suasana pembelajaran yang berkualitas, secara prinsip, guru memegang dua tugas pokok, yakni pengajaran dan pengelolaan kelas. Guru sebagai tenaga pendidik profesional memiliki peran yang sangat kompleks, tidak terbatas pada kegiatan pembelajaran, guru juga bertugas sebagai administrator, evaluator, konselor. Manajemen merupakan suatu seni untuk mendapatkan segala sesuatu dilakukan melalui orang lain. Proses pembelajaran yang baik akan meminimalkan kemungkinan terjadinya kegagalan serta kesalahan dalam pembelajaran. Guru penting memiliki kemampuan menciptakan kondisi belajar mengajar yang baik dan untuk mencapai tingkat efektivitas yang
\end{abstract}

\footnotetext{
${ }^{1}$ Dosen Pendidikan Guru Madrasah Ibtidaiyah, STAI Nurul Huda Kapongan Situbondo
} 
Zainal Arifin ${ }^{1}$

optimal dalam kegiatan instruksional kemampuan pengelolaan kelas. Tujuan dari penelitian ini adalah untuk membuktikan ada atau tidaknya hubungan antara penataan situasi belajar siswa dengan hasil belajar pendidikan Islam. Untuk mencapai tujuan penelitian maka digunakanlah pendekatan kuantitatif dengan korelasi. Untuk memperoleh informasi yang tepat penelitian instrumen penelitian yang digunakan ialah skala ceklis dan dokumen tes hasil belajar siswa. Kemudia data yang diperoleh dianalisis menggunakan analisis statistik dan rumus produk moment. Hasil penelitian ini menjelaskan 5\% sebesar 0,250 dari interval kepercayaan 1\% sebesar 0,325 , dengan $\mathrm{N}=60$, dan nilai $\mathrm{r}_{\mathrm{xy}}=1,26$. Maka dari hasil analisi penelitian menjelaskan terdapat hubungan antara penataan situasi belajar siswa dengan hasil belajar pendidikan Agama Islam di MI Nurul Huda Kapongan Situbondo. Adapun siswa yang menggunakan penataan situasi belajar yang baik akan mendapatkan hasil yang lebih baik dibandingkan dengan siswa yang tidak menggunakan penataan situasi belajar yang tidak baik, tentu akan berpengaruh terhadap hasil kecakapan belajar siswa tersebut, sehingga mendapatkan hasil yang tidak memuaskan.

Kata Kunci: Pendidikan Agama Islam, Situasi Belajar, Hasil Belajar

\section{Pendahuluan}

Dalam upaya meningkatkan mutu pendidikan tentu saja tidak akan berjalan mulus sebagaimana yang diharapkan tentu saja terdapat banyak sebuah persoalan yang salah satunya proses pembelajaran didalam kelas. Terkhusus pada proses pendidikan Islam, didalam kelas guru seolah-olah hanya menyuguhkan kegiatan menabung para murid menjadi celengan dan guru menjadi penabungnya dan yang terjadi bukanlah proses komonikasi, akan tetapi guru menyampaikan pertanyaan-pertanyaan dan mengisi tabungan yang di terima dan di tuangkan dengan patuh oleh para muridnya. ${ }^{2}$ Aktivitas komunikasi dalam pendidikan hanya sekedar sebuah mekanisme otomatik yang lebih bersifat formalistik belaka. ${ }^{3}$ Pada pola pendidikan semacam ini kreatifitas dan progresifitas individu menjadi sangat terpasung.

Dalam konsep pendidikan gaya bank ini, pengetahuan adalah sebuah anugerah yang di hibahkan oleh mereka yang menganggap dirinya berpegetahuan kepada mereka yang tidak memiliki pengetahuan maksudnya adalah (memindahkan ilmu dari otak yang satu ke otak yang lain) dalam analogi lain, dapat di katakan bahwa peserta didik seringkali di anggap sebuah botol yang setiap waktu di tuangi air hingga penuh kemudian di isi lagi, maka tumpahlah air itu dan menjadi sia-sialah proses pengisian air itu(pendidikan).

${ }^{2}$ Munir Abdullah, "Pendidikan Karakter Membangun Karakter Anak Sejak dari Rumah", Yogyakarta: Pedagogia, 2010, hal. 13

${ }^{3}$ Azisi \& Faisal Faliyandra, "Kosa Kata At Tahlil At Taqabuli (Analisis Konstrastif dalam Bahasa Indonesia dan Bahasa Arab)", AKSIS: Jurnal Pendidikan Bahasa dan Sastra Indonesia, 4 (1), 2020, 76-84 
Kita lihat kondisi peserta didik di kelas, mereka dalam keadaan terbelenggu dinamikanya bayangkan dalam waktu yang sangat lama, mereka belajar bertahun-tahun belum mampu memiliki keterampilan memadai tentang pendidikan. Jika kita amati saja misalkan, dalam waktu kurang lebih enam tahun belajar bahasa arab atau bahasa inggris peserta didikpun belum menguasai apa-apa bandingkan dengan mereka yang mengikuti kursus mereka tentu lebih dinamis ini merupakan hal yang sangat sederhana namun di cari jalan keluarnya.

Dalam praktik pendidikan yang demikian ini, sesungguhnya guru telah menjadi kaum penindas dan muridpun menjadi kaum yang tertindas alangkah ironisnya. Oleh karena itu pendidikan harus kembali pada wajahnya yang asli yaitu suatu proses transformasi nilai yang memanusiakan manusia. Pada kondisi demikian pendidikan di tantang untuk mengembalikan posisi distorsif nilai kemanusian yang terjadi saat sekarang ini dan pendidikan harus berperan aktif dalam membangun peserta didik terutama dan bangsa pada umumnya. ${ }^{4}$

Oleh karena itu proses belajar mengajar merupakan inti dari kegiatan pendidikan di sekolah agar tujuan pendidikan dan pengajaran berjalan dengan benar, maka perlu mengadminitrasikan kegiatan-kegiatan belajar mengajar yang lazim disebut administrasi kurikulum. Bidang mengadministrasian ini sebenarnya merupakan pusat dari suatu kegiatan di sekolah. Menurut Faliyandra mengemukakan bahwa tugas dan peran guru antara lain menguasai dan mengembangkan materi pelajaran, merencanakan dan mempersiapkan pelajaran sehari-hari. ${ }^{5}$

Dari penjelasan diatas peneliti ingin meneliti tentang hubungan antara penataan situasi belajar yang dilakukan oleh guru dengan hasil belajar siswa. Penelitian ini dilakukan di MI Nurul Huda Kapongan Situbondo dengan beberapa alasan: 1. Penggunaan model pembelajaran yang inovatif sudah terlaksanan dengan baik, 2. Dari hasil observasi pertama, siswa di MI Nurul Huda Kapongan Situbondo rata-rata telah memenuhi KKM yang telah ditentukan oleh sekolah. Maka tujuan penelitian yang akan dilakukan yaitu melihat hubungan atau korelasi antara situasi belajar siswa dengan hasil belajar pendidikan Agama Islam di MI Nurul Huda Kapongan Situbondo.

${ }^{4}$ Faisal Faliyandra, "Tri Pusat Kecerdasan Sosial: Membangun Hubungan Baik Antar Manusia Pada Lingkungan Pendidikan di Era Teknologi”, Literasi Nusantara, 2019, hal 45.

${ }^{5}$ Faisal Faliyandra, "Model Kooperatif GI berbasis Outdoor Study Meningkatkan Aktivitas dan Hasil Belajar IPA SD”, Jurnal Pendidikan Dasar Indonesia, 1(2),2017, 20-24. 
Zainal Arifin ${ }^{1}$

Pembahasan

Metode

Pendekatan penelitian yang digunakan ialah kuantitatif dengan jenis korelasi. Penelitian korelasi adalah jenis penelitian yang bermaksud untuk menganalisis hubungan antara variabel dalam suatu penelitian ${ }^{6}$. Variabel yang ada dalam penelitian ini ada dua yaitu variabel bebas dan variabel terikat, maka penelitian ini untuk mengetahui tingkat hubungan antara penataan situasi dan hasil belajar.

Populasi merupakan keseluruhan subjek dan objek yang mempunyai kualitas serta ciriciri tertentu yang ditetapkan oleh peneliti untuk dipelajari dan kemudian ditarik kesimpulan ${ }^{7}$. Dengan demikian populasi dalam penelitian ini adalah seluruh MI Nurul Huda Kapongan Situbondo. Lalu setelah populasi ditemukan, kemudia menentukan sampel penelitian. Pada penelitian ini teknik yang digunakan dalam pengambilan sampel menggunakan porposive sampling, dengan sampel seluruh kelas V di MI Nurul Huda Kapongan Situbondo.

Untuk mendapatkan data yang baik peneliti menggunakan instrumen jenis angket dan dokumentasi. Angket digunakan untuk melihat bagaimana proses situasi belajar yang dilakukan oleh guru di kelas. Dokumentasi digunakan untuk mendapatkan berbagai macam data hasil belajar yang telah dilakukan oleh siswa. Lalu Setelah itu data yang diperoleh dianalisis menggunakan korelasi product mement untuk mengetahui bagaimana Hubungan Antara Penataan Situasi Belajar Siswa dengan Hasil Belajar Pendidikan Islam di MI Nurul Huda Kapongan Situbondo.

\section{Hasil dan Pembahasan}

Pada hasil analisis data terhadap variable-variabel yang diukur, dapat dijelaskan bahwa penataan situasi belajar siswa berada pada kategori cukup baik (66,7\%) dan untuk variabel hasil belajar siswa Aqidah Ahklak Islam terdapat 40 responden sebanyak 8 orang (20\%) menunjukkan hasil belajar dengan kategori baik, sedangkan 32 orang (80\%) menunjukkan hasil belajar remedial dengan kategori kurang baik.

Koefisien korelasi (rxy) yaitu sebesar 0,552 dengan arah hubungan positif (+). Artinya antara variabel $\mathrm{x}$ dan $\mathrm{y}$ terdapat korelasi yang kuat dikarenakan koefisien korelasi 0,40 - 0,60.

${ }^{6}$ Sugiyono, "Metode Penelitian Kuantitatif Kualitatif dan R \& D”, Bandung:Alfabeta, 2010, hal 173

${ }^{7}$ Suharsimi Arikunto, "Prosedur Penelitian Suatu Pendekatan Praktik", Jakarta: Rineka Cipta, hal 68 
Hubungan ini dapat dilihat dari nilai Probabilitas Sig. $(0,000<\alpha$ 0,05), maka Ho ditolak. Jadi koefisien korelasi signifikan, artinya ada hubungan yang signifikan dan positif antara penataan situasi belajar siswa $(\mathrm{X})$ dan dengan hasil belajar siswa $(\mathrm{Y})$. Nilai t hitung $(4,078)>$ dari t tabel $(1,686)$ yang berarti terdapat pengaruh yang signifikan dari penataan situasi belajar siswa terhadap hasil belajar siswa Aqidah Ahklak Islam di MI Nurul Huda Kapongan Situbondo. Besarnya koefisien determinasi $(\mathrm{r} 2)=0,304$, hal ini berarti kontribusi penataan situasi belajar siswa $\mathrm{r}$ terhadap hasil belajar siswa Aqidah Ahklak Islam di MI Nurul Huda Kapongan Situbondo sebesar 30,4\%. sedangkan sisanya sebesar 69,6\%, hasil belajar siswa dipengaruhi oleh faktor-faktor lain yang tidak di teliti.

Berdasarkan hasil tersebut dapat disimpulkan bahwa penataan situasi belajar siswa dengan hasil belajar Aqidah Ahklak Islam di MI Nurul Huda Kapongan Situbondo memiliki hubungan yang positif dan signifikan (rhitung $>$ rtabel dan thitung $<$ ttabel) dimana nilai rhitung $(0.552)>\operatorname{rtabel}(0.312)$ dan thitung $(4,078)>11$ ttabel (1.686). yang berarti terdapat hubungan penataan situasi belajar siswa dengan hasil belajar siswa mata pelajaran Aqidah Ahklak di MI Nurul Huda Kapongan Situbondo.

Dari hasil penelitian di atas jelas bahwa penataan situasi belajar siswa memiliki hubungan dengan hasil belajar siswa. Oleh sebab itu, untuk meningkatkan hasil belajar siswa, salah satunya adalah guru melakukan penataan situasi belajar siswa itu sendiri, karena dengan adanya penataan situasi belajar siswa akan turut serta mengalami proses bagaimana memulai, merencanakan serta melakukan praktek mata pelajaran Aqidah Ahklak tersebut ${ }^{8}$. Dengan berusaha mengetahui proses dalam mempelajari materi pelajaran Aqidah Ahklak, sedikit banyak akan menumbuhkan penataan situasi belajar siswa untuk lebih meningkatkan hasil belajar yang diperoleh dari ujian yang diberikan. Pernyataan ini selaras dengan berbagai penelitian yang telah dilakukan; Pertama, menjelaskan bahwa terdapat hubungan positif manajemen kelas dengan kelancaran proses pembelajaran'; Kedua, terdapat hubungan antara manajemen kelas dengan hasil belajar siswa ${ }^{10}$

\footnotetext{
${ }^{8}$ Imam Baihaki, "Paradigma Pesantren Terhadap Pendidikan Karakter di Lembaga Formal", At-Turost: Journal of Islamic Studies, 7(1), 2020, 88-102

${ }^{9}$ Baiq Rohiyatun \& Sri Erni Mulyani, "Hubungan Prosedur Manajemen Kelas Dengan Kelancaran Proses Belajar Mengajar”, JUPE: Jurnal Pendidikan Mandala, 2(2), 92-99, 2017

${ }^{10}$ Idawati, "Hubungan Manajemen Kelas Dengan Hasil Belajar", Jurnal Riset Pendidikan Dasar, 02(01), 2933,2019
} 
Zainal Arifin ${ }^{1}$

Besarnya hubungan penataan situasi belajar siswa dalam meningkatkan hasil belajar siswa hendaknya menjadi tolak ukur bagi instansi penyelenggara pendidikan khususnya MI/SD yang sarat dengan pengusaan kelas yang nantinya bisa dikembangkan menjadi mensukseskan tujuan pembelajaran. Oleh sebab itu guru disekolah haruslah memiliki suatu ide untuk diaplikasikan pada proses pembelajaran yang ditunjukkan pada pengelolaan kelas ${ }^{11}$. Maka sekolah hendaknya dapat meningkatkan penataan situasi belajar siswa siswa yang dapat bermanfaat dan menjadi nilai tambah serta dapat menerapkan keterampilan yang telah dipelajari untuk lingkungan masyarakat sekitarnya.

\section{Penutup}

Belajar merupakan proses yang komperhensif didukung berbakai perspektif ilmu lainnya dengan harapan mensukseskan tujuan pembelajaran, yang direalisasikan dengan hasil belajar siswa. Untuk menganalisis lebih mendalam tentang hasil belajar, maka pada penelitian bertujuan untuk mencari hubungan antara situasi kelas dengan hasil belajar siswa. Dengan begitu, temuan dilapangan berdasarkan hasil analisis data, guru yang dapat mengelola situasi belajar berhubungan dengan siswa memperoleh nilai yang sangat baik. guru yang dapat mengelola situasi belajar sedang ada yang memperoleh nilai yang sangat baik dan ada pula yang memperoleh nilai yang baik. Sedangkan guru yang dapat mengelola situasi belajar rendah ada siswa yang sering mendapat nilai yang baik dan ada yang memperoleh nilai yang rendah. Guru yang dapat mengelola situasi belajar mempengaruhi hasil belajar siswa tetapi tidak sepenuhnya hasil belajar dipengaruhi oleh kedisiplinan. Hal ini dikarenakan hasil belajar tidak hanya dipengaruhi oleh kedisiplinan saja tetapi juga dipengaruhi oleh faktor-faktor yang lain seperti minat, bakat, kecerdasan, motivasi, dan sebagainya. Oleh karena itu, peneliti merekomendasikan untuk meneliti tentang hubungan minat, bakat, kecerdasan, motivasi dengan hasil belajar siswa.

\section{Referensi}

Abdullah, Munir. 2010. Pendidikan Karakter Membangun Karakter Anak Sejak dari Rumah. Yogyakarta: Pedagogia.

Achamadi. 2005. Ideologi Pendidikan Islam. Yogyakarta: Pustaka Pelajar.

\footnotetext{
${ }^{11}$ Faisal Faliyandra, "Model Komunikasi Pendidikan di Sosial Media Pada Era Perkembangan Teknologi, Islam Universalia, 1(3), 434-459, 2020.
}

40 | Jurnal Auladuna 
Arikunto, Suharsimi. 2014. Prosedur Penelitian Suatu Pendekatan Praktik. Jakarta : Rineka Cipta.

Azisi \& Faliyandra, Faisal. 2020. Kosa Kata At Tahlil At Taqabuli (Analisis Konstrastif dalam

Bahasa Indonesia dan Bahasa Arab). AKSIS: Jurnal Pendidikan Bahasa dan Sastra Indonesia, 4 (1), 76-84

Baihaki, Imam. 2020. Paradigma Pesantren Terhadap Pendidikan Karakter di Lembaga Formal. At-Turost: Journal of Islamic Studies, 7(1),88-102.

Faliyandra, Faisal. 2017. Model Kooperatif GI berbasis Outdoor Study Meningkatkan Aktivitas dan Hasil Belajar IPA SD. JPDI (Jurnal Pendidikan Dasar Indonesia), 1(2), 20-24.

Faliyandra, Faisal. 2019. Tri Pusat Kecerdasan Sosial "Membangun Hubungan Baik Antar Manusia Pada Lingkungan Pendidikan di Era Teknologi”. Literasi Nusantara

Faliyandra, Faisal. 2020. Model Komunikasi Pendidikan di Sosial Media Pada Era Perkembangan Teknologi. Islam Universalia, 1(3), 434-459.

Idawati. 2019. Hubungan Manajemen Kelas Dengan Hasil Belajar. Jurnal Riset Pendidikan Dasar, 02 (01), 29-33.

Majid, Abdul \& Andayani, Dian. 2011. Pendidikan Karakter Perspektif Islam. Bandung: PT Remaja Rosdakarya.

Nata, Abudin. 1996. Akblak Tasawuf. Jakarta: Raja Grafindo.

Rohiyatun, Baiq \& Mulyani, Sri Erni. 2017. Hubungan Prosedur Manajemen Kelas Dengan Kelancaran Proses Belajar Mengajar. JUPE: Jurnal Pendidikan Mandala, 2(2), 92-99.

Sugiyono. 2010. Metode Penelitian Kuantitatif Kualitatif dan R \& D. Bandung:Alfabeta, 2010. 